\title{
On the Tracks of Aswan Pink Clay. New Studies on the Local Clay Deposits in the Region of Aswan/Upper Egypt
}

\author{
Laura Rembart ${ }^{1}$, Lisa Betina ${ }^{2 *}$ \\ ${ }^{1}$ Austrian Archaeological Institute, Franz Klein-Gasse 1, 1190 Vienna, Austria \\ ${ }^{2}$ Saxo Institute, University of Copenhagen, Karen Blixens Plads 8, 2300 Copenhagen, Denmark
}

\section{ARTICLE INFO}

\section{Article history:}

Received: $9^{\text {th }}$ September 2020

Accepted: $28^{\text {th }}$ January 2021

DOI: http://dx.doi.org/10.24916/iansa.2021.1.3

Key words:

Egypt

pottery production

kaolinitic clay

geological fieldwork

\begin{abstract}
A B S T R A C T
Using Ptolemaic to late antiquity pottery assemblages from Aswan (ancient Syene) as a case study, we demonstrate the imperative nature of petrographic analyses combined with geological field surveys when investigating ancient potting centres. The combination of archaeological (i.e. abundance of ceramics, vessel shapes etc.), macroscopic and natural-scientific methods allows the reconstruction of the possible extraction areas of clays utilised in Aswan, Upper Egypt. Knowledge of specific clays and their compositional characteristics helps to establish archaeometric reference groups, necessary for differentiating kaolinitic clay sediments of the Aswan area from similar geological environments further down the Nile valley.
\end{abstract}

\section{Introduction}

One of the most important ceramic production centres of the post-Pharaonic period in ancient Egypt is situated in the Aswan region in Upper Egypt and it was specialised in the manufacture of ceramic artefacts made of so-called "Pink Clay". Modern Aswan is synonymous with the ancient cities of Syene and Elephantine, which evolved into a political and economic centre around the first Nile cataract already in the Ptolemaic period. Geographically, Syene represents the southernmost town in the Ptolemaic empire and subsequently in the Roman Empire. This prominent position, along with the nearby island of Elephantine, was of particular significance with respect to, for example, the exchange of goods with Nubia to the south, and trade with the well-known rose granite extracted from local quarries since Pharaonic times. The granite was distributed northwards through the river ports of both Syene and Elephantine.

Syene thus flourished, particularly due to the trade, and reached an economic upturn in Hellenistic times, which is recognizable by the expansion of the inhabited city area.

*Corresponding author. E-mail: lisa.peloschek@gmail.com
Elephantine was famous in Pharaonic times primarily because of its religious cult sites around the annual Nile flood. In the $5^{\text {th }}$ century $\mathrm{CE}$, the temple areas were successively released for secular development and the island remained despite the conquest of Upper Egypt by the Arabs in $642 \mathrm{CE}$ - continuously inhabited until the early Islamic period.

In 2011, the Austrian Science Fund-Project "Housing in Antiquity in Syene/Elephantine, Upper Egypt" directed by S. Ladstätter at the Austrian Archaeological Institute (OeAI) in cooperation with the Swiss Institute for Archaeological and Architectural Research on Ancient Egypt in Cairo (SIK) was begun. The main goal of this three-year project was a socio-cultural interpretation of Syene and Elephantine from the Late Ptolemaic period until late antiquity, based on the material legacy from different residential buildings. The pottery finds from Syene originate from excavations in Area 2 and Area 13c. In both areas residential buildings were uncovered which were used continuously from the Ptolemaic period to at least the middle Roman Imperial period; residential buildings with adjoining courtyards for household activities along narrow alleys have been uncovered, which have been rebuilt several times in the course of time. The pottery from Elephantine comes from residential complexes, 


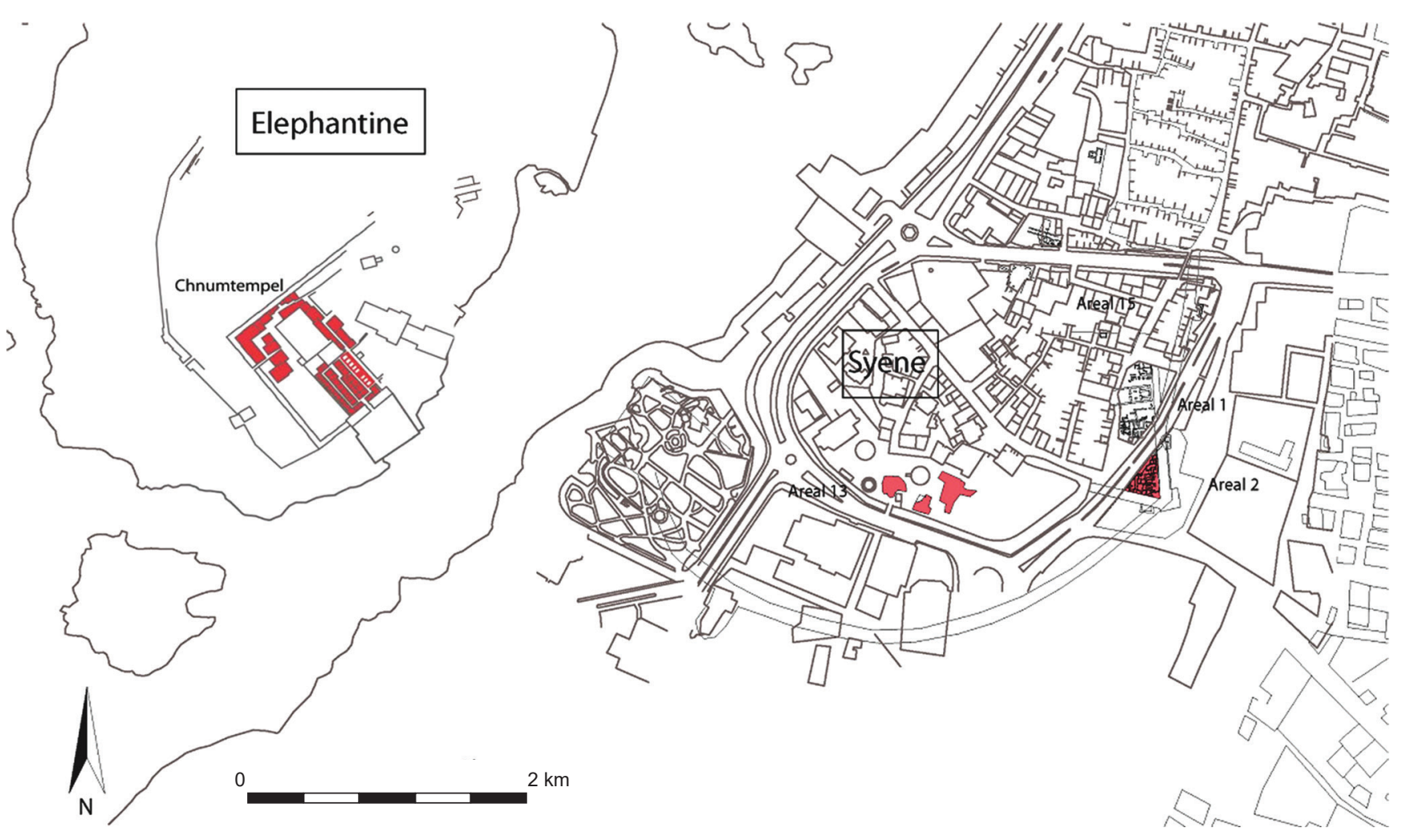

Figure 1. Map of Elephantine and modern Aswan (the excavation areas are marked in red).

so-called tower houses, which were built in the area of the former temple of Chnum in the $5^{\text {th }}$ century $\mathrm{CE}$ and were in use until the end of the $7^{\text {th }}$ century (Figure 1).

Petrographic analysis of the pottery was an essential component of the project in order to differentiate imported vessels from those produced in the local potteries of Aswan and its surroundings. Focus was hereby on ceramics macroscopically assigned to "Pink Clay", for which only a handful of references are available up to now. Petrographic signatures of the clay have been generated and a certain diversity in the mineral and rock inclusions noted, allowing the identification of four Aswan Pink Clay-variants.

In the following we report on a geological survey that has been conducted with the aim to identify potential source areas of these characteristic clays. Besides the collection of clay samples, the collection and subsequent analysis of rock samples was of particular significance, as in thin-section the mineral constituents and quantities of individual minerals in the rocks can be identified. Can traces of such rock fragments be found in the clays sampled in the region? Can traces of such rock fragments and their mineral compounds be detected in ancient pottery fragments? Most importantly, can the origin of Aswan Pink Clay from kaolinite weathered from granite be confirmed?

\section{State of research, methodology and theoretical approach}

In 2009, the recording of the pottery finds was initiated; some of the excavated layers consisted exclusively of ceramics, which meant that huge amounts of material were gathered. The pottery recording was carried out in several campaigns in Aswan and was limited on site to the find statistics, in which all fragments were counted and statistically registered. Furthermore, the ceramics have been graphically and photographically documented, and diagnostic pieces described in a Microsoft Access database containing all the relevant information, such as measurements, ceramic fabrics and decoration.

A total of nearly 200,000 pottery fragments were recorded statistically. Of these $5 \%$ were included in the database as diagnostic fragments - considered as such were rim and base fragments, as well as wall fragments with decoration, and also body sherds of imported pottery. These diagnostic fragments were assigned to the respective ware groups. In this regard, the material from Syene can be differentiated into tableware, coarseware, kitchenware, transport amphorae and lamps (Rembart, 2020).

For decades, the "Vienna System" has been used for the classification of Egyptian ceramics on a macroscopic level (basic reading: Arnold and Bourriau, 1993; Bourriau et al., 2000; Nordström and Bourriau, 1993). However, this system was developed for the description of Pharaonic ceramics from a limited number of archaeological sites and is therefore difficult to use for the Ptolemaic, Roman and late antiquity ceramic fabrics of Upper Egypt. For this reason, we deliberately refrained from using the Vienna System when processing the pottery from Syene and Elephantine and instead developed a guidance system based on new criteria, primarily considering the clays' mineral and rock 


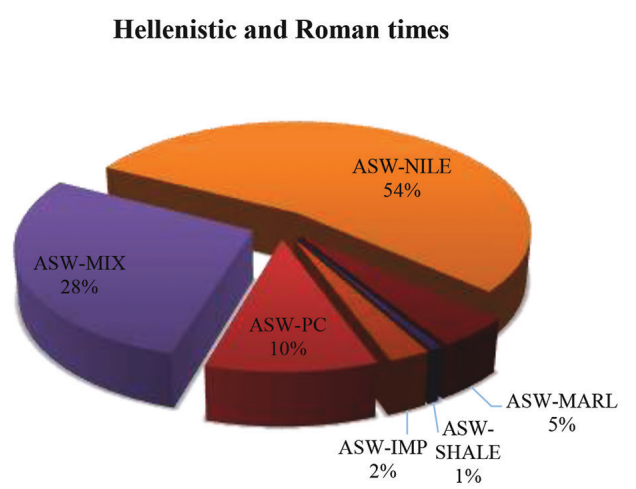

Figure 2. Distribution of the fabrics.

inclusions. The main focus of the analyses was on the local kaolinitic clay pastes subsumed under the term Aswan Pink Clay (Peloschek and Katzjäger, 2017; Katzjäger, Peloschek and Rembart, 2016).

Due to the exploitation of the native clay deposits, the region of Syene developed into a significant ceramic production centre at the beginning of the $2^{\text {nd }}$ century $B C E$ (Rembart, 2020). According to the completed statistical analysis, $10 \%$ of the vessels were made of the local clay paste in Hellenistic and Roman times, while $75 \%$ of the overall late antiquity ceramic material is represented by Aswan Pink Clay (Figure 2). This clay paste was used for the production of different kinds of wares and vessel forms, with tableware and amphorae dominating by far (Figure 3).

Based on the results of the statistical analysis of the archaeological ceramics, various research questions were developed. The most obvious one was the quantitative increase of ceramics fabricated from Aswan Pink Clay during the centuries, which made us wonder about the temporal dependency of the clay selection criteria. Can it be supposed

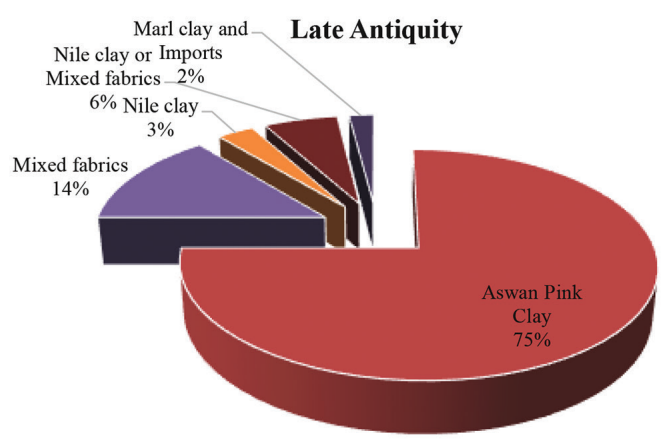

that the dramatic rise in the exploitation of Aswan Pink Clay over the centuries relates more to the expanding knowledge of mining sites of appropriate raw clays in the broader environs of Aswan? In order to review these assumptions, the composition and characteristics of the clays utilised in the pottery production and the raw materials accessible needed to be compared.

To consider macroscopic characteristics and vessel typology, 29 ceramic samples were taken for petrographic analysis. Geological clay and sediment samples were soaked in water, homogenised and levigated, before being fired at $850{ }^{\circ} \mathrm{C}$ in an electrical furnace and consequently thinsectioned. This allowed for a straightforward comparative analysis of both ceramic and clay samples.

\section{Results and discussion}

"Pink Clay" (Rodziewicz, 1992) is the term used in literature for an Egyptian clay tentatively connected to kaolinitic
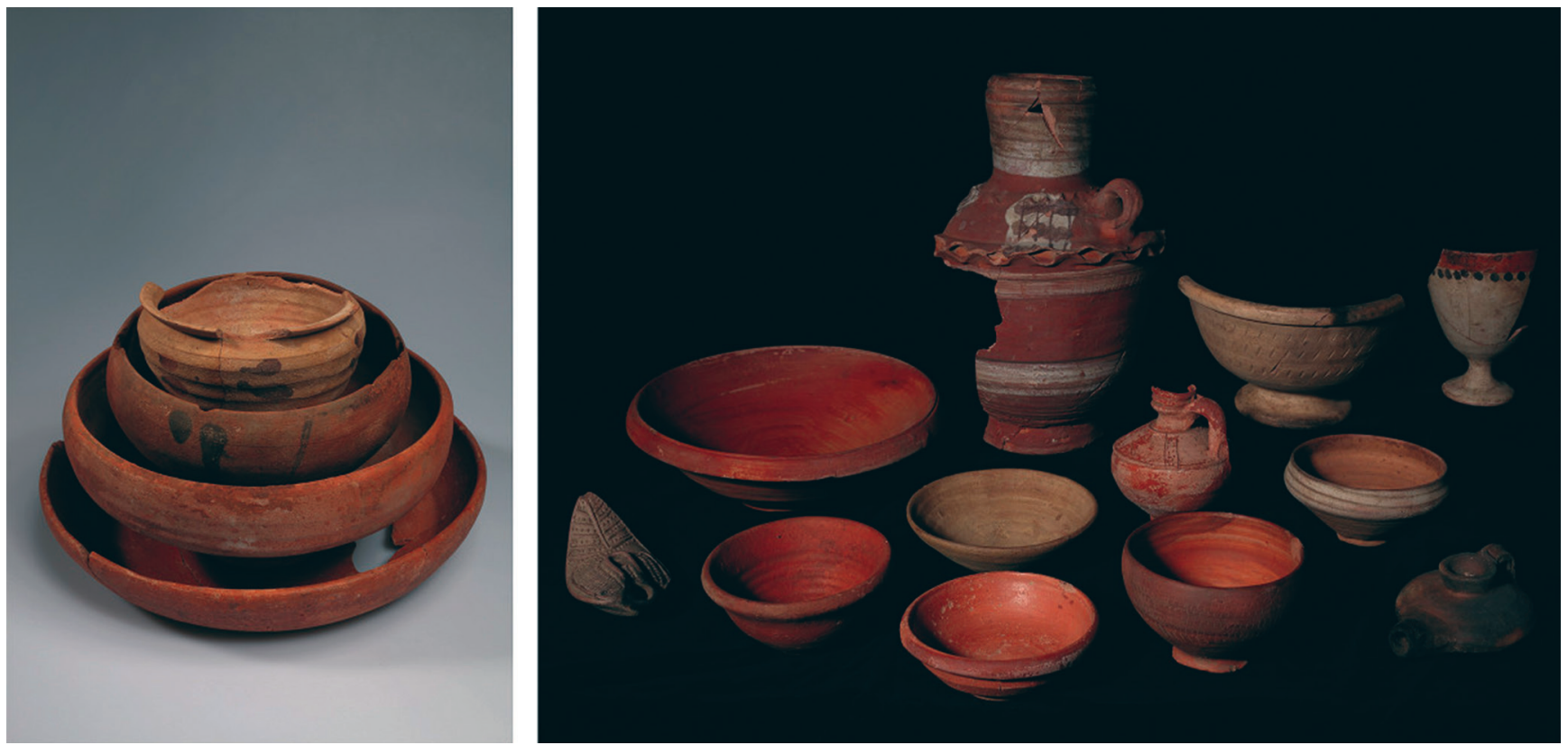

Figure 3. Collection of Roman and late antiquity tableware. 
sediments. The Aswan Pink Clay sediments are supposed to derive from the decomposition of pinkish feldspar minerals found in the local rose granite, available abundantly in the entire broader area (Soliman, 1985).

\subsection{Petrographic analysis}

Petrographic analyses allowed a differentiation of four clay pastes based on the character of non-plastic inclusions embedded in the clay matrices. The petrofabric ASW-PC_01 can be designated as the typical, most common Aswan Pink Clay already described by Tomber and Williams (1996) who were the first to examine a sherd of Aswan Pink Clay pottery in thin-section. Figure 4 highlights the most diagnostic characteristics of ASW-PC_01, defined amongst others by quartz, shale, kaolinitic clay pellets, feldspars, chert or volcanic rock inclusions in the coarse fraction. Rock fragments of granite, pellets of Nile mud or amphiboles can also occur in lower quantities. Petrofabric ASW-PC_04, is a relatively pure and fine-grained kaolinitic sediment containing only traces of shale, chert and volcanic rock fragments in a kaolinitic clay groundmass. Two other variants of Aswan Pink Clay deviate slightly: Petrofabric ASW-PC_02 has an increased content of
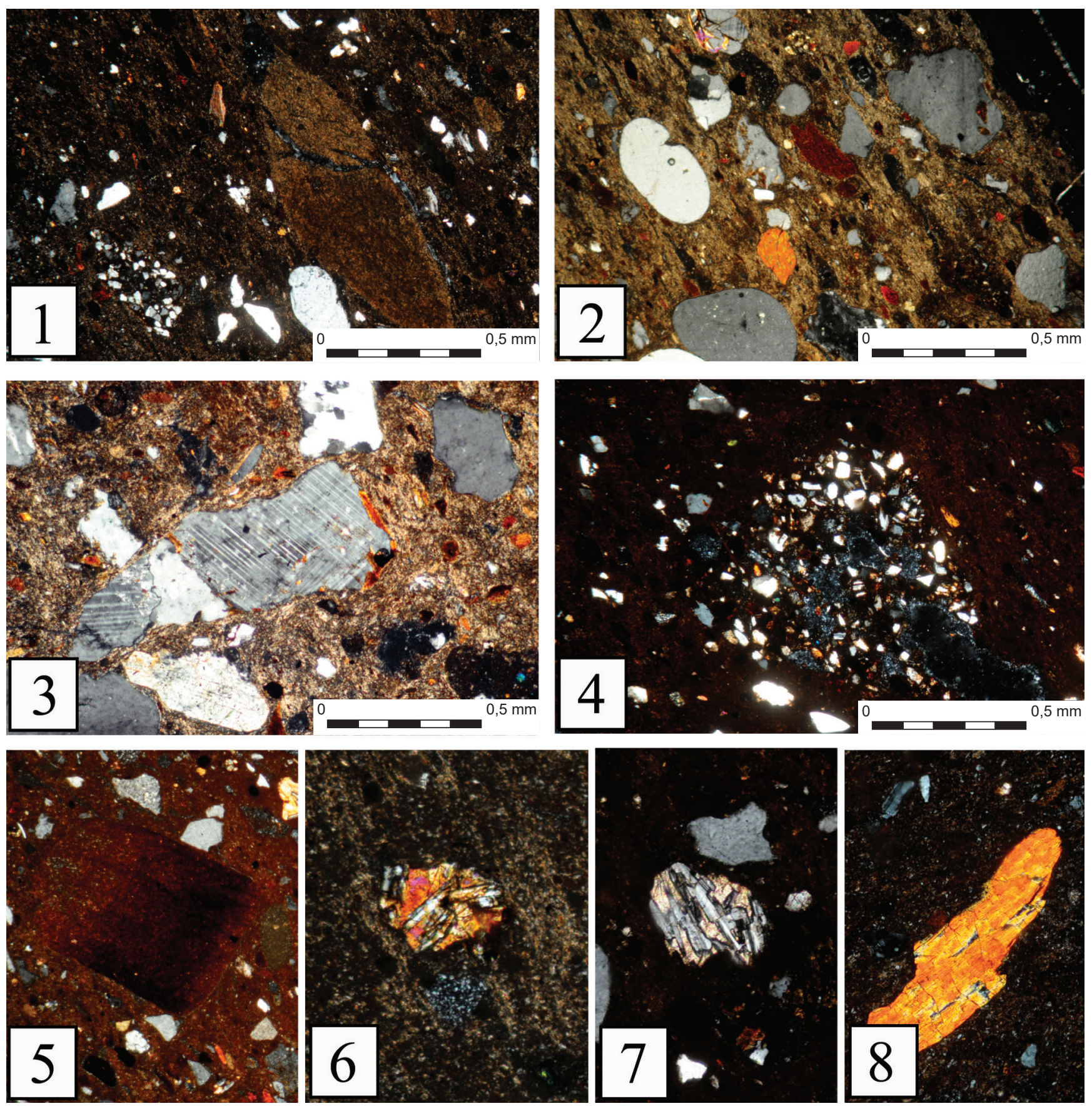

Figure 4. Characteristic inclusions of Aswan Pink Clay in thin-section (xpl): 1. Kaolinitic clay pellet; 2. Quartz, K-feldspars and amphibole; 3. Granite; 4. Pellet of Nile mud; 5. Shale; 6. and 7. Volcanic rock fragments; 8. Amphibole. 
dark-reddish to orange shale, already visible with the naked eye but otherwise matching the composition of ASW-PC 01 , and ASW-PC 03 is defined by an increased amount of opaque isotropic particles (Peloschek and Katzjäger, 2017). The clay pastes have been described in detail elsewhere (Katzjäger, Peloschek and Rembart, 2016, pp.731-732 with microphotographs).

A re-firing experiment (Katzjäger, Peloschek and Rembart, 2016) not only visualized that the clay gained the characteristic pinkish colour at $850^{\circ} \mathrm{C}$, which led to the name Pink Clay, but illustrated as well the different colour shades Aswan Pink Clay might exhibit. The firing experiment was conducted in an electrical furnace under controlled conditions at $750^{\circ} \mathrm{C}, 850^{\circ} \mathrm{C}, 950^{\circ} \mathrm{C}$ and $1050^{\circ} \mathrm{C}$; the heating rate was set to $200^{\circ} \mathrm{C} /$ hour with a soaking time of 1 hour at maximum temperature.

\subsection{Material remains in Aswan and the Nile valley}

Although no complete pottery workshop structures have been discovered in Syene to date, neither in the vicinity of the town, nor on Elephantine Island, ceramic wasters such as unfired or misfired pottery factually indicate the existence of potteries in this area (Rodziewicz, 2005; Peloschek, 2015). The remains of kilns as well as pottery waste were found between the modern Aga Khan mausoleum and the monastery of St. Simeon in the 1980s (Ballet et al., 1991; Ballet and Vichy, 1992). As a result, a possible production centre has been assumed along the West Bank of the Nile.
Two important remarks need to be made: a) The geology of Aswan and the area further north to Kom Ombo is relatively homogeneous, meaning that potentially clays with similar properties could have been provided from within an extensive area; b) The availability of kaolinitic clay sediments in the Nile valley spanning from Aswan to Nag el-Hagar (Figure 5, left), $30 \mathrm{~km}$ upstream, might complicate the pinpointing of possible areas of clay supply for Aswan's ceramic workshops; not least, because of the existence of yet another ceramic production centre in Nag el-Hagar. At least for late antiquity, a production centre can be documented due to production waste, such as discoloured body sherds from a rubbish heap. Preliminary investigations by the Institute of Prehistory and Archaeology of the Roman Provinces of the University of Munich, in cooperation with the SIK, on the pottery in this area revealed that Nag el-Hagar had a large manufactory of ERS A from the middle of the $5^{\text {th }}$ century until at least the middle of the $7^{\text {th }}$ century CE (Sieler, 2008; Mackensen and El Bialy, 2011).

Based on ceramic studies performed in Nag el-Hagar, we know that significant amounts of pottery macroscopically resembling Aswan Pink Clay have been recovered on site. Yet, it remains unknown if the vessels were produced by using the local kaolinitic sediment deposited around Nag el-Hagar, or if they represent imports from upstream, i. e. Aswan. This means that the attribution of pinkish kaolinitic clays to exclusively Aswan might be challenged. However, as long as no comparative geological and archaeometric data
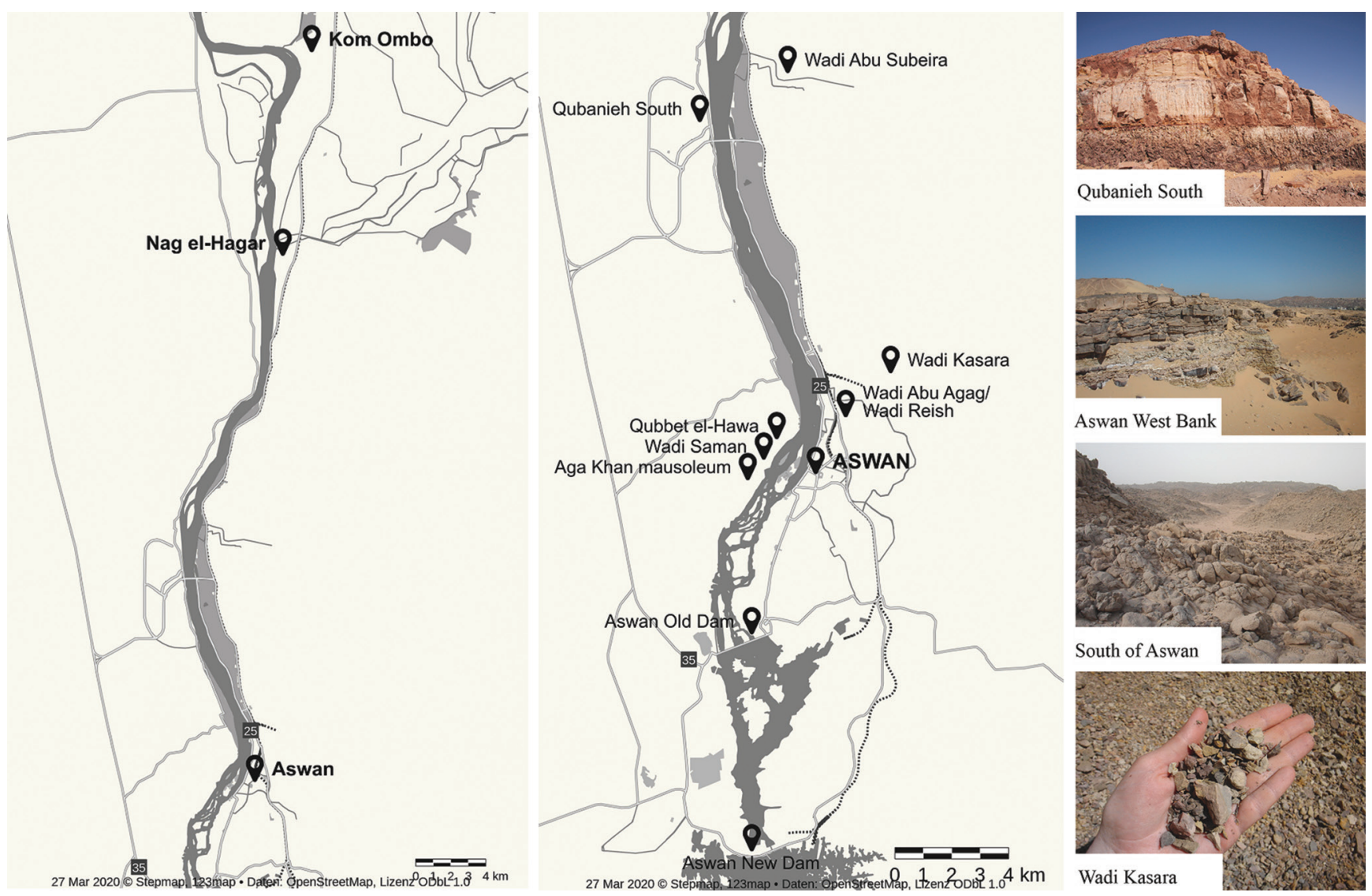

Figure 5. Geographic setting of Aswan, site locations visited in the course of geological field surveying and the clay resources of selected sites. 
for clays and ceramics from Nag el-Hagar is available, this issue remains ambiguous. It might well be that in the future the denomination of Egypt's pinkish clays - now known as Aswan Pink Clay - will need to be reconsidered.

\subsection{Planning of the geological fieldwork}

To gain a more precise idea about the local ceramic production of Aswan and especially the possible extraction areas of the four different clay pastes, a one-week geological field survey was conducted in February 2013. The survey covered an area of around $480 \mathrm{~km}^{2}$ between Wadi Abu Subeira in the north and the new Aswan Dam in the south (Figure 5, middle), whereby the sites of interest were investigated by photographing the geological formations and mapping the spots of interest. In November 2014 the survey was completed by taking geological samples from the relevant sites. These geological samples comprised clays, desert sand and rock specimens that best reflect the geology of the respective sites surveyed.

The main research questions concerned the geological homogeneity or heterogeneity of the Aswan region, specifically: Can clays of similar composition be found at different locations within that region? Or are distinctive clay compositions associated to particular sites? And, based on these observations, do the clay pastes utilised in ancient pottery production match or at least resemble the native clay deposits? And finally, is the evidence obtained from the geological field survey strong enough to prove with hard scientific data the exclusive production of Pink Clay Pottery in the Aswan region, or might similar ceramics have well been made also further downstream, e.g. around Nag el-Hagar?

The selection of the areas surveyed was based on four parameters:

- The results of petrographic analysis of archaeological ceramics: mineral and rock inclusions detected in thin-section already provided first indications about geological environments that clays might associate to.

- The available, often very generic geological maps of the region (bibliography: Peloschek and Katzjäger, 2017, p.1009): the maps indicate mainly alluvial deposits and outcrops of sandstone, iron ores, granite, granodiorite and metamorphic rocks (mostly schists). The extended area to the southeast of modern Aswan had been considered of particular interest, as here granites respective kaolinite - commonly considered as parent rock of Aswan Pink Clay - are most abundant.

- Locations where modern clay mining industries are still operating or have been recently abandoned: These are situated just north of modern Aswan.

- The immediate surroundings of ancient Syene and Elephantine: in particular, sites where ceramic wastes have been identified. Most important in this respect was Aswan's west bank around St. Simeon's monastery.

Following the collection of geological samples, the claystones and sediments were soaked in water, shaped into clay briquettes and fired in an electrical furnace. Thinsection petrography was chosen as the analytical method to investigate the samples. Although geochemical and mineralogical analyses would have definitely benefited a thorough characterisation of the clays, unfortunately, this was not an option. Firstly, the methods for archaeometric analyses available in Egypt are very limited. Secondly, while the export of ceramic samples and geological materials was possible in the past, it is now prohibited. This is also reflected in the uneven representation of analytical techniques consulted for the investigation of Egyptian ceramics over the past decades. Thin-section petrography dominates scientific analyses of Egyptian ceramics. Other scientific techniques have mainly been used decades ago when the export of archaeological ceramic samples was still allowed, or where analyses are being performed on the ceramics of museum collections abroad or on Egyptian ceramics uncovered on sites outside the country (most recently: Ting and Taxel, 2020).

\subsection{Implementation of geological fieldwork and results of the petrographic analysis of geological samples}

In turning to the results of the geological study (for site locations and illustrations compare Figure 5), it needs to be noted that Aswan's West Bank is mainly characterised by silicified sandstones, spreading north to at least as far as Qubanieh South. Clay sediments that might be identified as kaolinitic can be found interbedded with sandstone in various locations on the West Bank. Nevertheless, pinpointing a clay quarry in exactly the area between Qubbet el-Hawa and the Aga Khan mausoleum might need to be reconsidered: Bands of clay in this area are relatively thin, not plausibly supporting the theory of large-scale exploitation of clay raw materials, as would be expected for a mass production.

The East Bank of the Nile is characterised by a higher diversity of rock formations. In the north at Wadi Abu Subeira, kaolinitic clays again are associated with sandstones. It is further south around Wadi Abu Agag and Wadi Kasara that iron ore deposits are located in close proximity to the river Nile. Moreover, the presence of mica schists needs to be stressed. To the east of Wadi Kasara, again sandstone formations define the geological landscape. Metre-thick clay deposits are distributed in the whole area. However, sporadic granites must be native to the region, as pure kaolinite has been detected in a side valley between Wadi Abu Agag and Wadi Kasara.

South of Aswan, granites dominate the geological environment. Yet, kaolinitic clay has been identified in sediments washed off the weathered rocks, rather than appearing as massive clay deposits per se.

Starting with the area southeast of Aswan, between the Old and the New Aswan Dam, the dominance of granitic rocks defining the landscape is also evident in the clay samples. Fragments of granites, but also their minerals, such as feldspars and biotite, frequently occur in native clays. Noteworthy is, moreover, the presence of micritic limestone and microfossils, probably related to marls. These features do not correspond with the identified Aswan Pink Clay 
pastes, excluding the region as possible clay mining area exploited in antiquity.

Northeast of Aswan, just outside of the borders of the populated town, the case of Wadi Reish and Wadi Kasara, placed next to each other, can demonstrate the variability of clays in a micro-region. In Wadi Reish, being closer to the shore of the river Nile, the clays contain increased quantities of micrite and minerals deriving from granite. Further inland, in Wadi Kasara, the co-existence of granitic and metamorphic rocks can be proven through the analysed clay samples. Both sources can be excluded as potential clay mining areas in the Ptolemaic to late antiquity periods. However, following the Wadi further inland, highly kaolinitic clays in visually diverse clay colours have been identified. Microscopically, the clays are relatively fine, containing small amounts of quartz, chert and biotite, but an increased volume of shale. It appears that the amount and colour of variegated shale embedded in the clay is responsible for this diversity.

Modern clay mining businesses have been operated further north in Wadi Abu Subeira. Here, again, kaolinitic clays are deposited, being defined by the accessory minerals - quartz, muscovite, augite and amphiboles; a few sandstone fragments may also be embedded in the clay matrix. Kaolinitic clay groundmasses and shale components are distinctive for Aswan Pink Clay pottery, and the examples from Wadi Abu Subeira and the large outcrop at Wadi Kasara attest the occurrence of geologically related clays northeast of Aswan, although the accessory non-plastic components do not match in their entirety. The investigation of clays at Aswan's West Bank has been more promising. Shales combined with sandstone are widespread in this location, continuing also further northwards, as they have also been detected at Wadi el Faras and Qubanieh South.

Traces of chert and shale have both been found in Aswan Pink Clay pottery and the geological samples. This evidence might imply a relation to deposits of bedded chert, describing chert interbedded with shale caused by silica diagenesis (compare the formation of chert from microcrystalline silica/ quartz). The presence of minerals such as clinopyroxenes, amphiboles, serpentine and volcanic rock fragments in these primary clays is surprising. A similar spectrum of inclusions is symptomatic for Nile sediments. Aswan Pink Clay, particularly variant petrofabric ASW-PC_01, has been defined as a possibly natural mixture of kaolinitic sediments and Nile mud in varying quantities. Taking into consideration the results of our raw clay analyses, the scale of Nile sediments as ingredients of Aswan Pink Clay pastes needs to be re-evaluated.

The best match of a clay source and ceramic fabric comes from Wadi Saman, just opposite Elephantine island on the West Bank. The clay groundmass is kaolinitic, the spectrum of inclusions comparable; shales and opaque minerals are both present. Also, macroscopically the clay exhibits a greyish colour before and soft pinkish colour after firing. Clays geologically similar to this example, but exposed at various localities, might have been used as (base) material for the manufacture of ancient pots. It might be suspected that a certain natural variability of this clay at the West Bank of Aswan, or also the extended area, is given, which might result in the diversity of the four Aswan Pink Clay pottery fabric variants.

\section{Conclusion}

By combining archaeological and archaeometric methods in the analysis of pottery found in Aswan, possible areas appropriate for clay mining in antiquity have been identified. Based on the results of the clay analyses, it is reasonable to identify the clay deposits located at Aswan's West Bank as those most closely related to ancient potting resources, although the occurrence of similar clays in areas not surveyed or around Nag el-Hagar, cannot be excluded.

Yet it is evident that the clays used in the fabrication of Aswan Pink Clay ceramics were not extracted from exactly the same spots that we sampled, but appropriate clay beds with abundant raw material might have existed nearby. In order to narrow down the areas of possible provenance for Aswan Pink Clay, more archaeometric reference data is needed, especially from Nag el-Hagar. Assessing the character of the ceramics produced will certainly contribute to a better understanding of Greco-Roman ceramic industries in the south of Egypt.

Explanation models for the intensified use of kaolinitic clay pastes in late antiquity compared to the Ptolemaic and Roman Imperial period are uncertain. The functional benefits of the comparably hard-firing clay pastes, but also their aesthetic means due to the appealing reddish to pinkish colour of the ceramics after firing, certainly supported or initiated a mass production of Aswan Pink Clay-pottery. The wide distribution of the ware throughout the entire Mediterranean and beyond in the late antiquity period is clear testimony for this assumption.

Appropriate clay raw materials were available at all times and, as shown, present in close proximity to the studied consumption sites of both Syene and Elephantine. Although kaolinitic clays similar to the composition of petrofabric ASW-PC_01 can be found in the broader environs of modern Aswan, it is reasonable to assume that the clays had been mined in proximity to the settlements of ancient Syene and Elephantine rather than being quarried at more distant locations. Yet, we do not know the exact sites of the pottery workshops producing the ceramics under investigation, but it is likely to presume the craft branches to have run their businesses within or just a little outside the ancient habitation zone - even more so, as this meant that access to the river Nile was provided, facilitating a distribution of the ceramics, and ultimately leading to the status of Aswan as a major ceramic production centre.

\section{References}

ARNOLD, D., and BOURRIAU, J., eds., 1993. An Introduction to Ancient Egyptian Pottery. SDAIK, 17. Mainz: von Zabern. 
BALLET, P., MAHMOUD, F., VICHY, M. and PICON, M., 1991. Artisanat de la céramique dans l'Égypte romaine tardive et byzantine. Prospections d'ateliers de potiers de Minia à Assouan. Cahiers de la Ceramique Egyptienne, 2, 129-143.

BALLET, P. and VICHY, M., 1992. Artisanat de la céramique dans l'Égypte hellénistique et romaine. Ateliers du Delta, d'Assouan et de Kharga. Cahiers de la Ceramique Egyptienne, 3, CCE, 3, 109-119.

BOURRIAU, J.D., SMITH, L.M. V. and NICHOLSON, P.T., 2000. New Kingdom Pottery Fabrics. Nile clay and mixed Nile/Marl clay fabrics from Memphis and Amarna. Fourteenth Occasional Publication. London: The Egypt Exploration Society.

KATZJÄGER, D., PELOSCHEK, L. and REMBART, L., 2016. The Multiplicity of Aswan Pink Clay Pottery (Roman Times to Late Antiquity). Synchronising Shape Repertoire, Clay Pastes and Firing Properties. Rei Cretariae Romanae Fautorum acta, 44, 731-736.

MACKENSEN, M., EL-BIALY, M., 2011. Fourth Report of the EgyptianSwiss Joint Mission at the Late Roman Fort at Nag al-Hagar near Kom Ombo. Annales du Service des Antiquités de l'Égypte, 2008, 243-258.

NORDSTRÖM, H.-A. and BOURRIAU, J., 1993. Ceramic Technology: Clays and Fabrics. In: D. Arnold, and J. Bourriau, ed. An Introduction to Ancient Egyptian Pottery. Mainz: von Zabern, pp. 144-190.

PELOSCHEK, L. and KATZJÄGER, D., 2017. Archaeological and mineralogical profile of the Aswan Pink Clay-pottery from late antique Elephantine (Upper Egypt). In: D. Dixneuf, ed. Late Roman coarse wares, cooking wares and amphorae in the Mediterranean. Archaeology and archaeometry. LRCW, 5(2). Etudes Alexandrines, 43. Alexandria: Centre d'Études Alexandrines, pp. 997-1009.

REMBART, L., 2020, Syene IV. Die ptolemäische und römische Keramik aus den Arealen 2 und 13c. Typochronologie und weiterführende Studien. Beiträge zur Ägyptischen Bauforschung und Altertumskunde, 22, Gladbeck: PeWe-Verlag.

RODZIEWICZ, M.D., 1992. Field notes from Elephantine on the Early Aswan Pink Clay Pottery. Cahiers de la Ceramique Egyptienne, 3, 103-107.

RODZIEWICZ, M.D., 2005. Early Roman Industries on Elephantine, Elephantine, 27, Archäologische Veröffentlichungen, 107, Mainz: von Zabern.

SOLIMAN, M.M., 1985, Some textural patterns and their bearing on the origin of the granitic rocks of the Aswan region, south Egypt. Journal of the University of Kuwait (Sci), 12, 299-308.

SIELER, M., 2008. Egyptian Red Slip Ware A and its production at the site of the late Roman fort at Nag el-Hagar/Upper Egypt. Rei Cretariae Romanae Fautorum Acta, 40, 271-278.

TING, C., and TAXEL, I., 2020. Indigeneity and Innovation of Early Islamic Glaze Technology: The Case of the Coptic Glazed Ware. Archaeological and Anthropological Sciences, 12, 12-27.

TOMBER, R., and WILLIAMS, D., 1996. An Egyptian Red Slip “A” Sherd from London. Britannia, 27, 382-385. 